\title{
IKLIM MIKRO DAN RESPON HEMATOLOGI KELINCI LOKAL (Lepus nigricollis) PADA JENIS KANDANG BERBEDA
}

\author{
NURIYASA I.M. \\ FAKULTAS PETERNAKAN UNIVERSITAS UDAYANA \\ madenuriyasa@yahoo.com.
}

\begin{abstract}
ABSTRAK
Salah satu kendala dalam pengembangan ternak kelinci adalah ternak ini sensitif terhadap perubahan faktor lingkungan. Pergeseran kondisi lingkungan (iklim mikro ) dari kebutuhan optmimum menyebabkan penurunan produktivitas. Kandang yang lebih sesuai dengan kondisi lingkungan merupakan salah satu solusi untuk mengurangi cekaman panas di daerah dataran rendah tropis. Percobaan dilaksanakan dengan menggunakan Rancangan Acak Kelompok (RAK) dengan tiga perlakuan dan 5 kali ulangan. Perlakuan pertama adalah: kandang under ground shelter (Ko), Kandang alas semen (K1) dan perlakuan ketiga adalah: kandang battery (K2). Kelinci yang dipergunakan adalah kelinci jantan lokal lepas sapih dengan umur 4-5 minggu. Variabel yang diamati adalah iklim mikro kandang dan respon hematologi ternak kelinci jantan lokal. Kandang Ko menyebabkan temperatur dalam kandang lebih rendah $(\mathrm{P}<0,05)$ daripada kandang $\mathrm{K} 2$, namun tidak berbeda nyata $(\mathrm{P}>0,05)$ dibandingkan dengan K1. Kelembaban udara dalam kandang K2 lebih tinggi $(\mathrm{P}<0,05)$ daripada K1 dan Ko. Tidak terjadi perbedaan yang nyata $(\mathrm{P}>0,05)$ pada variabel intensitas radiasi, suhu maksimum dan suhu minimum pada perlakuan kandang berbeda. Tidak terjadi perbedaan yang nyata pada kandungan hematokrit, glukosa, dan trigliserida darah ternak kelinci yang dipelihara pada kandang berbeda. Kelinci yang dipelihara pada kandang Ko dan K1 menghasilkan kandungan haemoglobin dan eritrosit lebih tinggi $(\mathrm{P}<0,05)$ daripada K2, sedangkan kandungan leukosit darah kelinci yang dipelihara pada kandang K2 lebih tinggi $(\mathrm{P}<0,05)$ daripada Ko dan K1 Dari hasil penelitian dapat disimpulkan bahwa kandang under ground shelter dan kandang alas semen menyebabkan iklim mikro dan respon hematologi lebih baik daripada kandang battery.
\end{abstract}

Kata kunci : Jenis kandang berbeda, Iklim mikro dan respon hematologi

\section{MICRO CLIMATE AND HEMATOLOGIC RESPONSES OF MALE LOCAL RABBIT (Lepus nigricollis) HOUSED IN THE DIFFERENT TYPE CAGES}

\begin{abstract}
Rabbit is an animal that is too sensitive to the environment changes (micro climate) Uncomfortable environmental conditions cause a decrease in productivity of the rabbit. Cage selection that is more ideal to the environmental conditions is one of the solutions to reduce heat stress in rabbits lowland tropics. The experiment was conducted by using Rendomized Complete Design with three treatments and five replications. The first treatment is: under ground shelters (Ko), the second treatment is: cement floor cage (K1) and the third treatment is: battery (K2). The research used male local rabbits, aged 4 to 5 weeks. The variables observed on this study were namely microclimate of cages and hematologic responses of the rabbit. Air temperature in the Ko cage was lower $(\mathrm{P}<0.05)$ than the K2 cage, but not significantly different $(\mathrm{P}>0.05)$ from K1. Humidity in the cage K2 was higher $(\mathrm{P}<0.05)$ than K1 and Ko cages. There is no significant differences $(\mathrm{P}>0.05)$ in the variables: intensity of the radiation, maximum temperature and minimum temperature at different cages. There is no significant differences $(\mathrm{P}>0.05)$ in the content of hematocrite, glucose, and blood triglycerides of rabbits that was housed in different cages. Rabbits housed in Ko and $\mathrm{K} 1$ cages produce hemoglobin and erythrocytes content of rabbit blood was higher $(\mathrm{P}<0.05)$ than the K2, while the it leukocyte content of rabbit blood it could be housed in K2 cage was higher $(\mathrm{P}<0.05)$ than Ko and K1 cages. From the results of this study concluded that under ground shelter and cement floor cage caused micro-climate and hematologic responses is better than battery.
\end{abstract}

Key words : Different cage, micro climate and hematologic response. 


\section{PENDAHULUAN}

Pengembangan usaha peternakan kelinci merupakan trobosan strategis dalam bidang peternakan untuk mempercepat tercapainya swasembada pangan khususnya daging pada tahun 2014 (Dirjennak, 2011). Ternak kelinci mempunyai keunggulan dalam kualitas daging kerena kandungan protein daging tinggi dan rendah lemak. Dibalik karakteristik unggul yang dimiliki, ternak kelinci juga memiliki faktor penghambat yaitu sensitif terhadap perubahan faktor lingkungan.

Sampai saat ini, informasi hasil penelitian tentang kelinci lokal yang berhubungan dengan faktor lingkungan khususnya iklim mikro dan respon hematologi masih belum banyak. Temperatur dan kelembaban udara, lama penyinaran, ketinggian tempat, akumulasi $\mathrm{NH}_{3}$ dan kebisingan merupakan variabel faktor lingkungan yang harus diperhatikan pada peternakan kelinci (Lick dan Hung, 2008).

Ternak kelinci tergolong homeotherm, dimana ternak kelinci akan selalu berusaha mempertahan suhu tubuhnya dengan cara mengatur produksi panas dan jumlah panas yang dilepaskan ke lingkungan. Adaptasi yang dilakukan ternak kelinci melalui proses hemeostatis tidak akan berjalan epektif bila kondisi lingkungan melampaui batas yang dapat ditoleransi oleh ternak kelinci. Pada kondisi ini ternak kelinci akan mengalami cekaman (stress). Ternak melepaskan panas tubuhnya dengan cara konduksi, konveksi, radiasi dan evaporasi. Pemeliharaan ternak ternak kelinci dengan sistem under ground shelter dan kandang lantai semen memungkinkan ternak untuk melepaskan panas tubuhnya dengan cara konduksi melalui media lantai kandang yang bertemperatur lebih rendah dari temperatur tubuh ternak (Esmay, 1978). Menurut Suc et al. (1996) adanya lubang tempat berlindung pada kandang under ground shelter memungkinkan kelinci ke luar masuk lubang untuk menyeimbangkan panas tubuh dengan panas lingkungan. Pemeliharaan ternak sistem battery (panggung) berarti memperpendek jarak antara ternak dengan bahan atap kandang dan penyesuaian temperatur melalui pergerakan angin. Nuriyasa (1991) mendapatkan bahwa bahan atap kandang berperan sebagai penyumbang panas yang terukur dalam kandang dengan proporsi terbesar. Kondisi tersebut menyebabkan makin dekat jarak antara ternak dengan bahan atap kandang, berarti makin tinggi pula temperatur udara yang terukur di lingkungan ternak. Radiasi matahari (radiasi gelombang pendek) yang diterima mengalami perubahan menjadi radiasi gelombang panjang (efek panas) dan diemisikan ke ruangan kandang. Suc et al. (1996) mendapatkan bahwa sistem pemeliharaan ternak kelinci dengan lantai tanah yang dilengkapi dengan lubang berlindung (under ground shelter) menyebab- kan temperatur udara rata-rata dalam lubang berlindung adalah $25,9^{\circ} \mathrm{C}$ dan kelembaban udara $80,4 \%$ sedangkan temperatur udara dengan kandang battery adalah $29,4^{\circ} \mathrm{C}$ dan kelembabab udara $75,9 \%$.

Bali beriklim tropika basah, dengan temperatur berkisar $21,87^{\circ} \mathrm{C}$ sampai $31.13^{\circ} \mathrm{C}$ dan kelembaban udara berada pada rentang $79 \%-86 \%$ (BMKG, 2012) yang sesungguhnya kurang ideal untuk pengembangan ternak kelinci, terlebih lagi pada daerah dataran rendah. Menurut Yan dan Li (2008) ternak kelinci memerlukan temperatur nyaman $20^{\circ} \mathrm{C}$. Cekaman panas akan direspon oleh ternak kelinci melalui mekanisme hematologi (Vanessa, 2005).

Dari uraian tersebut di atas, manarik untuk dikaji iklim mikro yang ditimbulkan oleh kandang berbeda serta respon hematologi ternak kelinci sebagai respon terhadap perbedaan iklim mikro kandang.

\section{MATERI DAN METODE}

Penelitian dilaksanakan di desa Dajan Peken, Tabanan dengan ketinggian tempat $150 \mathrm{~m}$ dari permukaan laut yang berlangsung selama 3 bulan yaitu dari bulan April sampai Juni 2011. Penelitian menggunakan Rancangan Acak Kelompok (RAK) dengan tiga perlakuan dan 5 ulangan. Pengelompokan dilakukan berdasarkan berat badan.

Kandang under ground shelter dibuat pasangan batoko setinggi $45 \mathrm{~cm}$ kelinci tidak mudah lepas. Di atas batako di pasang kawat agar kandang tidak gelap dan memudahkan pengamatan. Kandang under ground shelter dilengkapi dengan lubang tempat berlindung dengan sudut kemiringan tempat masuk adalah $45^{\circ}$, panjang $35 \mathrm{~cm}$ dan lebar $30 \mathrm{~cm}$ dengan lubang masuk $20 \mathrm{~cm}$. Kandang alas semen dibuat dengan cara yang sama dengan under ground shelter namun tidak dilengkapi dengan lubang tempat berlindung. Kandang battery dibuat dalam bentuk panggung dengan ketinggian bangunan kandang dari tanah adalah $75 \mathrm{~cm}$. Rangka kandang terbuat dari kayu ukuran $4 \mathrm{~cm}$ x $6 \mathrm{~cm}$, kayu 3 $\mathrm{cm} \times 5 \mathrm{~cm}$ dan kayu reng. Sisi samping kandang di tutup dengan anyaman kawat dengan diameter lubang 3 $\mathrm{cm}$. Bagian bawah kandang terbuat dari anyaman kawat agar ternak faeses dan air kencing dapat terbuang dengan mudah. Petak kandang battery berukuran panjang $70 \mathrm{~cm}$, lebar $50 \mathrm{~cm}$ dan tinggi petak kandang.

Kelinci jantan lokal umur 5 minggu sebanyak 20 ekor dengan berat badan 199,45g $\pm 1,05$ dipergunakan dalam percobaan ini. Ransum diberikan dalam bentuk pellet dengan kandungan energi termetabolis 2400 $\mathrm{kkal} / \mathrm{kg}$, protein kasar 16\% dan serat kasar (12\%), sesuai standard McNitt et al. (1996). 


\section{Variabel Penelitian \\ Iklim Mikro Kandang}

Pengukuran variabel iklim mikro kandang dilakuan pada periode awal penelitian, pertengahan penelitian dan akhir penelitian, masing-masing selama tujuh hari. Dalam satu hari dilakukan tiga kali pengukuran yaitu pukul 7.30 wita, 13.30 wita dan 17.30 wita.

Data temperatur dan kelembaban udara dalam kandang diukur dengan menggunakan thermohygrometer digital tipe $\mathrm{CE}$ 11/o8. Pada kandang battery dan kandang alas semen, temperatur dan kelembaban udara di ukur pada lima titik yaitu pada masing-masing sudut kandang dan titik tengah kandang. Hasil pengukuran pada lima titik ini di rata-ratakan untuk mendapatkan satu data temperatur yang representatif pada satu petak kandang. Pengukuran temperatur dan kelembaban udara pada kandang under ground shelter dilakukan dengan cara yang sama dan ditambah pengukuran temperatur udara pada lubang tempat berlindung. Pengukuran dilakukan pada setiap unit percobaan (petak kandang) dan dilakukan tiga kali sehari yaitu pagi hari pada pukul 7.30 wita, siang hari pada pukul 13.30 wita dan sore hari pada pukul 17.30 wita. Temperatur rata-rata harian didapat dengan menggunakan formulasi Handoko (1995) sebagai berikut:

Selanjutnya data rata-rata temperatur udara harian dijumlahkan dan dibagi dengan jumlah hari pengamatan untuk mendapatkan temperatur udara rata-rata selama penelitian. Kelembaban udara rata-rata didapatkan dengan menjumlahkan ketiga data pengamatan (pagi, siang dan sore) kemudian dibagi tiga. Temperature Humidity Index (THI) untuk ternak kelinci dihitung dengan formulasi Marai (2002) sebagai berikut :

$\mathrm{THI}=\mathrm{T}-[(0,31-0,31 \times \mathrm{RH})(\mathrm{T}-14,4)]$

Keterangan:

THI : Temperature Humidity Index

$\mathrm{T}:$ Temperatur rata-rata dalam petak kandang $\left({ }^{\circ} \mathrm{C}\right)$

RH : Kelembaban relatif/100

Temperatur maksimum dan minimum mengindikasikan rentang temperatur yang terjadi pada masingmasing petak kandang pada satu hari. Pengukuran dilakukan dengan menggunakan termometer maksimum-minimum Six Bellani. Jumlah masing-masing temperatur maksimum dan minimum dibagi dengan jumlah hari pengamatan merupakan rata-rata temperatur maksimum dan minimum selama penelitian.

Pengukuran intensitas radiasi matahari dilakukan dengan menggunakan light meter digital merk Lutron tife LX-103 dan pengukuran dilakukan tiga kali sehari yaitu pukul 7.30, 13.30 dan 17.30 wita. Rata-rata intensitas radiasi matahari dalam satu hari didapatkan dengan menjumlahkan data pengamatan pada pukul 7.30, 13.30 dan 17.30 wita kemudian dibagi tiga.

\section{Variabel Hematologi}

Pengamatan terhadap variabel hematologi yang terdiri dari rata-rata kandungan hemoglobin (\%), jumlah eritrosit $\left(10^{6} / \mu \mathrm{l}\right)$, jumlah leukosit $\left(10^{3} / \mu \mathrm{l}\right)$, kandungan hematokrit (\%), kandungan glukosa darah (mg/100 ml), dan kandungan trigliserida darah $(\mathrm{mg} / 100 \mathrm{ml})$, sesuai dengan metode Nugraha (2010). Pengamatan dilakukan hanya sekali pada akhir penelitian setelah kelinci berumur 17 minggu. Sampel darah diambil pagi hari sebelum kelinci diberi makan dan air minum. Cara pengambilan contoh darah dilakukan dengan menusukkan jarum pada vena telinga, kemudian disedot dengan spyit plastik dan segera dipindahkan ke tabung reaksi yang telah terisi zat anti beku darah. Zat anti beku darah yang digunakan adalah lithium heparin (Xiangmei, 2008). Jumlah sampel darah yang diambil adalah sebanyak 6 cc untuk satu ekor kelinci (Nugraha, 2010). Segera setelah itu dimasukkan ke dalam termos es dan pada hari itu dikirim ke Laboratorium Kesehatan Masyarakat, Bina Medika, Denpasar untuk analisis hematologi.

\section{HASIL}

Dari hasil penelitian didapatkan bahwa kandang under ground shelter atau Ko dan kandang alas semen (K1) menyebabkan temperatur udara dalam kandang lebih rendah $(\mathrm{P}<0,05)$ daripada kandang battery atau K2. (Tabel 1). Kelembaban udara pada kandang K2 masing-masing 6,25\% dan $2,30 \%$ lebih tinggi $(\mathrm{P}<0,05)$ dibandingkan dengan kandang K1 dan Ko. Temperature Humidity Index pada kandang Ko dan K1 lebih rendah $(\mathrm{P}<0,05)$ daripada kandang $\mathrm{K} 2$. Tidak terjadi perbedaan yang nyata $(\mathrm{P}>0,05)$ terhadap variabel intensitas radiasi matahari, temperatur maksimum dan temperatur minimum pada perlakuan kandang yang berbeda.

Tabel 1. Iklim Mikro dan Respon Hematologi Ternak Kelinci pada Kandang Berbeda

\begin{tabular}{lrrrr}
\hline \multirow{2}{*}{ Variabel } & \multicolumn{3}{c}{ Perlakuan } & \multirow{2}{*}{ SEM } \\
\cline { 2 - 4 } & \multicolumn{1}{c}{ K0 } & \multicolumn{1}{c}{ K1 } & \multicolumn{1}{c}{ K2 } & \\
\hline Temperatur Udara $\left({ }^{\circ} \mathrm{C}\right)$ & $27,02^{\mathrm{b}}$ & $27,11^{\mathrm{b}}$ & $28,87^{\mathrm{a}}$ & 0,07 \\
Kelembaban Udara (\%) & $75,07^{\mathrm{b}}$ & $75,18^{\mathrm{b}}$ & $76,84^{\mathrm{a}}$ & 0,05 \\
Temperature Humidity Index $(\mathrm{THI})$ & $25,91^{\mathrm{b}}$ & $26,09^{\mathrm{b}}$ & $27,83^{\mathrm{a}}$ & 0,18 \\
Intensitas Radiasi Matahari $(\mathrm{fc})$ & $6,01^{\mathrm{a}}$ & $6,14^{\mathrm{b}}$ & $5,96^{\mathrm{a}}$ & 0,95 \\
Temperatur Maksimum $\left({ }^{\circ} \mathrm{C}\right)$ & $30,87^{\mathrm{a}}$ & $30,99^{\mathrm{b}}$ & $31,27^{\mathrm{a}}$ & 0,22 \\
Temperatur Minimum $\left({ }^{\circ} \mathrm{C}\right)$ & $21,87^{\mathrm{a}}$ & $21,02^{\mathrm{a}}$ & $21,08^{\mathrm{a}}$ & 0,16 \\
Haemoglobin $(\mathrm{g} / 100 \mathrm{ml})$ & $14,88^{\mathrm{a}}$ & $14,84^{\mathrm{a}}$ & $13,82^{\mathrm{b}}$ & 0,04 \\
Eritrosit $\left(10^{6} / \mu \mathrm{I}\right)$ & $4,19^{\mathrm{a}}$ & $4,18^{\mathrm{a}}$ & $4,13^{\mathrm{b}}$ & 0,003 \\
Leukosit $\left(10^{3} / \mu \mathrm{l}\right)$ & $6,05^{\mathrm{b}}$ & $6,06^{\mathrm{b}}$ & $6,39^{\mathrm{a}}$ & 0,13 \\
Hematokrit $(\%)$ & $42,71^{\mathrm{a}}$ & $41,77^{\mathrm{a}}$ & $40,21^{\mathrm{a}}$ & 1,05 \\
Glukosa $(\mathrm{mg} / 100 \mathrm{ml})$ & $181,36^{\mathrm{a}}$ & $180,42^{\mathrm{a}}$ & $175,61^{\mathrm{a}}$ & 14,75 \\
Trigliserida $(\mathrm{mg} / 100 \mathrm{ml})$ & $100,11^{\mathrm{a}}$ & $100,05^{\mathrm{a}}$ & $105,53^{\mathrm{a}}$ & 4,64 \\
\hline
\end{tabular}

1) KO : Kandang under ground shelter

K1 : Kandang Battery

2) Superskrip yang sama pada baris yang sama menunjukkan perbedaan tidak nyata $(P>0,05)$ dan superskrip berbeda pada baris yang sama menunjukkan perbedaan nyata $(P<0,05)$

3) SEM : Standard Error of The Treatment Means 
Kelinci yang dipelihara pada kandang Ko menyebabkan kandungan haemoglobin $0,27 \%$ lebih tinggi ( $\mathrm{P}>0,05)$ daripada $\mathrm{K} 1$ dan $7,12 \%$ lebih tinggi $(\mathrm{P}<0,05)$ daripada kandang K2. Kandungan eritrosit kelinci yang dipelihara pada kandang Ko 0,24\% lebih tinggi $(\mathrm{P}>0,05)$ daripada K1 dan 1,14\% lebih tinggi $(\mathrm{P}<0,05)$ daripada kandang K2. Kandang K2 meneyebabkan kandungan leukosit darah kelinci masing-masing 5,16\% dan 5,32\% lebih tinggi $(\mathrm{P}<0,05)$ dibandingkan dengan $\mathrm{K} 1$ dan Ko. Tidak terjadi perbedaan yang nyata $(\mathrm{P}>0,05)$ pada variabel hematokrit, glukosa dan trigliserida darah kelinci pada perlakuan kandang berbeda.

\section{PEMBAHASAN}

\section{Iklim Mikro}

Kandang under ground shelter (Ko) dan kandang alas semen (K1) menyebabkan temperatur udara lebih rendah daripada kandang battery bentuk panggung (K2). Menurut Lean dan Rind (1996) radiasi matahari merupakan faktor pengendali unsur iklim paling dominan dalam kandang disamping faktor lain seperti angin dan kelembaban udara. Kandang K2 yang berbentuk panggung dengan ketinggian $0,75 \mathrm{~cm}$ dari permukaan tanah menerima radiasi gelombang panjang lebih banyak daripada kandang Ko dan K1. Jarak yang lebih jauh antara atap dengan lantai kandang menyebabkan makin banyak radiasi gelombang panjang yang diabsorbsi oleh material atmosfer (aerosol, gas dan uap air) sehingga radiasi matahari gelombang panjang yang sampai di petak kandang lebih kecil. Radiasi matahari gelombang panjang ini yang akan terukur sebagai temperatur udara dalam kandang. Keadaan ini menyebabkan temperatur udara pada kandang Ko dalebih rendah daripada K1. Pantulan radiasi matahari gelombang pendek dari lingkungan kandang juga berpengaruh terhadap temperatur udara di dalam petak kandang. Dari data pengukuran dengan menggunakan light meter digital didapatkan bahwa tidak terjadi perbedaan intensitas radiasi matahari yang diterima oleh jenis kandang berbeda (Tabel 1). Hal tersebut mengindikasikan bahwa perbedaan temperatur yang terjadi pada kandang berbeda bukan disebabkan oleh perbedaan intensitas radiasi matahari yang diterima. Ternak dalam kandang akan menyeimbangkan panas tubuhnya dengan cara melepas kelebihan panas tubuhnya melalui proses konduksi, konveksi dan radiasi. Besaran panas yang dilepaskan ke lingkungan kandang mempengaruhi temperatur yang terukur di dalam kandang (Esmay, 1978). Hasil penelitian Suc et al. (1996) mendapatkan hasil yang sama yaitu kandang under ground shelter menghasilkan temperatur udara lebih rendah daripada kandang battery $\left(25,9^{\circ} \mathrm{C}\right.$ vs $\left.29,4^{\circ} \mathrm{C}\right)$. Perbedaan hasil pengukuran temperatur yang didapat disebabkan karena perbedaan ukuran kandang dan kedalaman lubang tempat berlin- dung yang dipergunakan. Kandang dengan ukuran dan kedalaman lubang lebih besar mempunyai kemampuan yang lebih besar menurunkan temperatur dalam petak kandang.

Kelembaban udara pada kandang K2 lebih tinggi daripada Ko dan K1. Kelembaban udara relatif merupakan perbandingan antara uap air yang ada di udara dengan kandungan uap air jenuh. Evaporasi dari air minum, saluran pernafasan dan ekskreta merupakan sumber uap air yang terkandung dalam udara (Oke, 1978). Temperatur udara dalam kandang K2 lebih tinggi daripada kandang K1 dan Ko sehingga evaporasi dari sumber air pada kandang K2 lebih tinggi dan kelembaban udara yang ditimbulkan lebih tinggi.

Kandang Ko dan K1 menyebabkan nilai THI lebih rendah daripada kandang K2. Temperatur dan kelembaban udara yang lebih rendah pada kandang Ko dan K1 menyebabkan nilai THI berada dalam kisaran nyaman. Marai et al. (2002) memberikan batasan kondisi nyaman pada ternak kelinci apabila nilai THI berada pada kisaran di bawah 27,8. sedangkan nilai THI pada kandang Ko mempunyai nilai THI 25,91. Dilihat dari nilai THI, kandang Ko $(25,91)$ dan K1 $(26,09)$ berada dalam kondisi nyaman bagi ternak kelinci. Ternak kelinci yang dipelihara pada kandang K2 dengan nilai THI 27,83 mengalami cekaman panas tingkat sedang.

Tidak terjadi perbedaan intensitas radiasi matahari yang masuk ke dalam kandang yang berbeda. Radiasi matahari yang masuk ke dalam kandang merupakan radiasi pantulan dari permukaan tanah disekitar kandang dan radiasi baur dari atmosfer. Semua petak kandang berada dalam satu bangunan yang sama, dengan satu sisi bangunan terbuka (tanpa tembok) sehingga intensitas radiasi matahari yang diterima oleh masing-masing petak kandang tidak jauh berbeda. Kedaan ini juga menunjukkan pengacakan petak kandang atau lokasi petak kandang di dalam ruangan kandang mendapat intensitas radiasi matahari yang sama.

Temperatur maksimum pada kandang K2 lebih tinggi dibandingkan dengan kandang K1 dan Ko. Jarak antara petak kandang dengan bahan atap menyebabkan radiasi gelombang panjang dari bahan atap intensitasnya lebih tinggi pada kandang K2 sehingga temperatur maksimum yang terukur lebih tinggi. Temperatur minimum pada kandang K2 lebih rendah dibandingkan K1 dan Ko. Kondisi ini disebabkan karena aliran angin dingin di luar kandang lebih kencang pada kandang K2 daripada K1 dan Ko. Rozari (1987) menyatakan gaya gesek permukaan makin besar seiring dengan makin dekat jarak antara aliran angin dengan permukaan tanah. Gaya gesek permukaan menyebabkan laju aliran angin makin berkurang. Pasangan batako setinggi 40 $\mathrm{cm}$ pada kandang Ko juga berfungsi sebagai pemecah angin sehingga dapat menghambat laju aliran angin 
dingin menuju petak kandang, pada saat temperatur minimum di luar kandang terjadi.

\section{Respon Hematologi}

Kandungan haemoglobin kelinci yang dipelihara pada kandang Ko dan K1 lebih tinggi daripada K2. Hal ini berkaitan dengan tingkat kenyamanan ternak dalam kandang yang selanjutnya berpengaruh pada proses metabolisme nutrien dalam tubuh ternak. Kandang Ko dan K1 meyebabkan nilai THI lebih rendah (lebih nyaman) dibandingkan dengan kandang K2. Pemeliharaan ternak dalam kondisi lingkungan lebih nyaman menyebabkan kebutuhan energi untuk hidup pokoknya lebih rendah. Keadaan ini menyebabkan proses pembentukan organ tubuh termasuk haemoglobin darah lebih tinggi.

Kandungan eritrosit darah kelinci yang dipelihara pada Ko dan K1 lebih tinggi daripada K2. Tingkat kenyaman ternak dalam kandang yang lebih tinggi menyebabkan efisiensi penggunaan ransum dan pertumbuhan meningkat. Tingkat pertumbuhan yang lebih tinggi menyebabkan pembentukan eritrosit meningkat karena sangat diperlukan dalam transportasi oksigen.

Berdasarkan penelitian ini didapatkan bahwa kelinci yang dipelihara pada kandang K2 memiliki kandungan leukosit darah lebih tinggi daripada kandang Ko dan K1. Peningkatan kandungan leukosit darah pada kandang K2 merupakan respon ternak terhadap kondisi cekaman panas, sesuai dengan pendapat Vanessa et al. (2005). Pada Tabel 1 nampak bahwa temperatur, kelembaban dan nilai THI pada kandang K2 lebih tinggi (kurang nyaman) dibandingkan kandang Ko dan K1.

Perlakuan jenis kandang berbeda tidak berpengaruh terhadap kandungan glukosa dan trigliserida darah. Tingkat cekaman panas yang dialami kelinci pada kandang berbeda belum berpengaruh terhadap mobilisasi glukosa dari simpanan glikogen atau penggantian sumber energi asal lemak (glukoneogenesis).

Dari hasil penelitian dapat disimpulkan bahwa kandang under ground shelter dan kandang lantai semen menyebabkan iklim mikro kandang lebih nyaman untuk ternak kelinci daripada kandang battery. Kelinci yang dipelihara pada kandang under ground shelter dan lantai semen menghasilkan respon hemetologi lebih baik dibandingkan dengan kandang battery.

\section{UCAPAN TERIMA KASIH}

Penulis menyampaikan terima kasih banyak kepada Bapak Rektor, Ketua LPPM Universitas Udayana beserta staf yang telah membiayai penelitian ini melalaui dana DIPA Unud tahun angggaran 2011. Terima kasih juga penulis sampaikan kepada Bapak Dekan Fakultas Peternakan beserta staf atas ijin menggunakan fasilitas laboratorium sehingga penelitian ini dapat terlaksana.

\section{DAFTAR PUSTAKA}

BMKG. 2009. Informasi Cuaca, Iklim dan Gempa Bumi Provinsi Bali. Bulletin. Tahun III No. o9 September 2009. Balai Besar Meteorologi Klimatologi dan Geofisika Wilayah III, Denpasar.

Dirjen Peternakan. 2011. Keijakan dan Pengembangan Sapi Bali dalam Mendukung Program Swasemada Daging Sapi. Seminar Nasional Sapi Bali. Universitas Udayana.

Esmay, M.L. 1978. Principles of Animal Environment. Avi Publishing Company, Inc., Westport, Connecticut.

Handoko. 1995. Klimatologi Dasar, Landasan Pemahaman Fisika Atmosfer dan Unsur-Unsur Iklim. Penerbit Pustaka Jaya, Jakarta.

Lean, J., D. Rin. 1996. The Sun and Climate. http://grico. org/CONSEQUENCES/winter 96/index.html. Disitir Tanggal 24 Juli 2010.

Lick, N.Q. and D.V. Hung. 2008. Study and Design the Rabbit Coop Small-Scale Farm in Central of Vietnam. Departemen of Agriculture Engineering, Hue University of Agriculture and Forestry. Vietnam.

Marai, I.F.M., A.A.M. Habeeb, A.E. Gad. 2002. Rabbits Productive, Reproductive and Physiological Performance Traits as Affected by Heat Stress. Departement of Animal Production, Faculty of Agiculture, Zagazig University, Zagazig, Egyt.

Mc.Nitt, J.I., N.M. Nephi, S.D. Lukefahr and P.R. Cheeke. 1996. Rabbit Production. Interstate Publishers,

Nugraha, K.A. 2010. Laboratorium Klinik: Pemeriksaan Darah (Blood Analysis). http://Komitekeperawatanrsdsoreang.blogspot.com/2010/02/laboratoriumklinik-pemeriksaan-darah/html. Disitir Tanggal 12 Nopember 2010.

Nuriyasa, I.M. 1991. Pengaruh Bahan Atap dan Kepadatan Kandang terhadap Penampilan Ayam Pedaging (tesis). Program Pascasarjana Institut Pertanian Bogor.

Oke. T.R. 1978. Boundry Layer Climate. Methmen dan Co. London.

Rozari, Mr.Bl,de. 1987. Iklim Mikro. Bahan Training Dosen Tinggi Negeri Indonesia Bagian Barat Dalam Bidang Agroklimatologi. IPB ,Bogor.

Suc, Q. N. D.V. Binh,L.T.T. Ha and T.R. Preston. 1996. Effect of Houshing System (Cage versus Underground Shelter) on Performance of Rabbits on Farm. Finca Ecologica, University of Agriculture and Forestry .http:// www.Irrd.org/Irrd8/4/cont 84.htm. Disitir Tanggal 12 Nopember 2010.

Steel, R.G.D. and J.H. Torrie. 1980. Prinsip dan Prosedur Statistika. Suatu Pendekatan Biometrik, Edisi kedua. Diterjemahkan Oleh Sumantri. Gramedia. Jakarta.

Vanessa, K.L., L.H. Tarpley and K.S. Latimer. 2005. Leukocyte Identification in Rabbits and Guinea Pigs. http:// www.vet.uga.edu/vpp/clerk/lester/ . Disitir Tanggal 24 Pebruari 2012.

Yan, Y and Li, M. 2008. Feeding Management and Technology of Breeding Rabbit in Hot Climate. Qingdao Kanada Food Company Limited Kanada Group, Qingdao, 26640o, China.Yanyk@vip.sina.com. 